Pesq. Vet. Bras. 35(12):947-950, dezembro 2015 DOI: $10.1590 / \mathrm{S} 0100-736 \mathrm{X} 2015001200002$

\title{
Equine infectious anemia on Marajo Island at the mouth of the Amazon river ${ }^{1}$
}

\author{
Nayra F.Q.R. Freitas ${ }^{2 *}$, Carlos M.C. Oliveira ${ }^{2}$, Rômulo C. Leite ${ }^{2}$, Jenner K.P. Reis ${ }^{3}$, \\ Fernanda G. Oliveira ${ }^{3}$, Henrique dos A. Bomjardim ${ }^{2}$, Felipe M. Salvarani ${ }^{2}$ \\ and José Diomedes Barbosa ${ }^{2}$
}

\begin{abstract}
Freitas N.F.Q.R., Oliveira C.M.C., Leite R.C., Reis J.K.P., Oliveira F.G., Bomjardim H.A., Salvarani F.M. \& Barbosa J.D. 2015. Equine infectious anemia on Marajo Island at the mouth of the Amazon river. Pesquisa Veterinária Brasileira 35(12):947-950. Instituto de Medicina Veterinária, Universidade Federal do Pará, Rodovia BR-316 Km 61, Bairro Saudade, Castanhal, PA 68740-970, Brazil. E-mail: diomedes@ufpa.br

Equine infectious anemia (EIA) is a transmissible and incurable disease caused by a lentivirus, the equine infectious anemia virus (EIAV). There are no reports in the literature of this infection in Equidae on Marajo Island. The objective of this study was to diagnose the disease in the municipalities of Cachoeira do Arari, Salvaterra, Santa Cruz do Arari and Soure, on Marajó Island, state of Pará, Brazil. For serological survey samples were collected from 294 horses, over 5-month-old, males and females of puruca and marajoara breeds and from some half-breeds, which were tested by immunodiffusion in Agar gel (AGID). A prevalence of $46.26 \%(136 / 294)$ positive cases was found. EIA is considered endemic in the municipalities studied, due to the ecology of the region with a high numbered population of bloodsucking insect vectors and the absence of official measures for the control of the disease.
\end{abstract}

INDEX TERMS: Equine infectious anemia, EIA, diagnosis, serology.

RESUMO.- [Anemia infecciosa equina na Ilha de Marajó na foz do Rio Amazonas.] A anemia infecciosa equina (EIA) é uma importante enfermidade, transmissível e incurável causada por um lentivírus, equine infectious anemia vírus (EIAV), e não há relatos na literatura desta infecção em equinos da Ilha de Marajó. 0 objetivo deste estudo foi diagnosticar a anemia infecciosa equina nos municípios de Cachoeira do Arari, Salvaterra, Santa Cruz do Arari e Soure, Ilha de Marajó, no bioma amazônico do estado do Pará, Brasil. Para a pesquisa sorológica foram coletadas 294 amostras de animais da espécie equina, acima de cinco meses de idade, de ambos os sexos, das raças puruca, marajoara e de mestiços, testadas pela imunodifusão em gel de Agar (IDGA). Foi verificada uma prevalência de 46.26\%

\footnotetext{
${ }^{1}$ Received on May 25, 2015.

Accepted for publication on December 5, 2015.

${ }^{2}$ Instituto de Medicina Veterinária, Universidade Federal do Pará, Rodovia BR-316 Km 61, Bairro Saudade, Castanhal, PA 68740-970, Brazil. E-mails: diomedes@ufpa.br, diomedes.barbosa.neto@gmail.com; *Corresponding author: nayraffreitas@gmail.com

${ }^{3}$ Departamento de Medicina Veterinária Preventiva, Escola de Veterinária, Universidade Federal de Minas Gerais (UFMG), Av. Presidente Antônio Carlos 6627, Cx. Postal 567, Belo Horizonte, MG 31270-901, Brazil.
}

(136/294) de casos positivos para EIA. A doença é considerada endêmica nos municípios estudados, tanto pelos aspectos ecológicos da região que propiciam a manutenção da população de insetos hematófagos vetores, quanto pela ausência de medidas oficiais de controle da doença.

TERMOS DE INDEXAÇÃ̃O: Anemia infecciosa equina, EIA, diagnóstico, sorologia.

\section{INTRODUCTION}

Equine infectious anemia (EIA) is a transmissible and incurable disease caused by a lentivirus, the equine infectious anemia virus (EIAV) which causes a persistent infection in horses (Leroux et al. 2004). EIA represents an obstacle in the raising and development of Equidae, causing great economic losses, preventing the improvement of breeds and access to the international equestrian market (Almeida et al. 2006).

As observed in the Brazilian Pantanal where EIA is much prevalent, on Marajó Island horses have an essential role for livestock development, due to their characteristics of high strength to environmental adversity, adaptation to climatic conditions and the island. The marajoaras and pu- 
ruca breeds as well as their half-breeds are used for field work, transportation, besides tourist programs for sports and leisure (Marques et al. 2001).

Given the importance that this disease has for Equidae associated with the role that horses play in the development of livestock on the island, the aim of this study was to determine the prevalence of EIA on Marajó Island, at the mouth of the Amazon river, since there are no reports in the literature of this infection for this region.

\section{MATERIALS AND METHODS}

The study was conducted with horses from farms in the municipalities of Cachoeira do Arari, Salvaterra, Santa Cruz do Arari and Soure, located one Marajo Island, state of Pará, Brazil. We collected 294 blood samples from over 5-month-old male and female horses of puruca and marajoara breeds as well as their half-breeds, by vacuum jugular venipuncture for serology. The protocol recommended by the MAPA was applied, according to the ordinance 84/1992 (Brasil 2004) in which was performed the agar gel immunodiffusion (AGID), official test for the diagnosis of Equine infectious anemia (EIA), Coggins et al. (1972). It was used the commercial kit containing antigen p26 and positive standard serum, by Bruch ${ }^{\circledR}$, starting 002/2012.

It was also performed blood count in 65 samples, of which 16 were from animals that were positive in AGID. As for serum biochemistry exam, other 70 different samples were tested, 30 positive animals for EIA and 40 negative. Was dosed urea, creatinine, aspartate aminotransferase (AST), alanine aminotransferase (ALT), gamma glutamyl transferase (GGT), alkaline phosphatase, total bilirubin and direct bilirubin. To carry out these tests were used commercial kits $\left(\right.$ Bioclín $^{\circledR}$, Cepa $^{\circledR}$, Doles $^{\circledR}$ ) and the readings were held in spectrophotometer (Bioplus, Bio 2000 model).

\section{RESULTS AND DISCUSSION}

From the 294 blood serum samples tested, 136 were positive for EIA, indicating a prevalence of 46.26\% (136/294), which is the first serological survey for the disease held in the Marajó region. This high rate of positive cases appears to be related to the horse breeding characteristics in the island region. According to the collection of epidemiological data on the farms studied, the horses are raised ultra-extensively, without serological control which would favor the diagnosis of asymptomatic carrier animals, which are an important source of infection (Cook et al. 2013), thus favoring the permanence of seropositive animals in coexistence with uninfected healthy animals.

Another relevant factor is that the Marajó Island remains flooded for part of the year, the water is kept dammed in natural lakes, as well as having favorable temperature and humidity conditions, ensuring the proliferation of vector insects (Brasil 2007); especially flies from the Tabanidae family, which are the main source for transmission of the disease (Issel \& Foil 1984, Pena et al. 2006, Gregg \& Polejaeva 2009, Karam et al. 2010, Issel et al. 2012). During the past five years poor handling conditions of the horses had been observed, that showed severe health problems, nutritional deficiencies, and parasitic, bacterial and viral infections, such as encephalomyelitis, responsible for many deaths in the archipelago (Campos et al. 2013).

A prevalence of $17.71 \%$ of horses positive for EIA was found by Heinemann et al. (2002) in the municipality of Uruará, southwestern Pará state, what shows that the disease is not limited to Marajó Island. The authors also point out to the ecological conditions of the Amazon region as the main factor for the occurrence of the disease, since it enables the development of blood-sucking insects as vectors for EIA. But Pena et al. (2006) found a seropositivity of $1.34 \%$ in southern Pará, which is possibly related to the fact that farms located in this region are characterized by large estates, which have a better developed organizational structure, with a more appropriate sanitary control.

When comparing the prevalence found in this study with those described in other regions of Brazil, we found that EIA continues to reach worrying proportions in areas with similar geo-climatic characteristics of the island, such as the Pantanal of Mato Grosso (Thomassian 2005, Melo et al. 2012). The midwestern and northern regions of the country also have a high level of seropositivity, approximately $12.7 \%$ and $11.8 \%$ respectively (Riet-Correa et al. 2007) as well as some areas of the states of Minas Gerais (Almeida et al. 2006).

In the evaluation of the red series, the average and standard deviation found for negative and positive horses are listed in Table 1. When compared the average of the results obtained in this study with the reference values for the equine species, it was found that they are within the range considered normal. Even being in physiological levels, the number of erythrocytes in positive animals was significantly lower than in negative animals. There was no significant difference between positive and negative when measured hemoglobin concentration values, hematocrit and platelet counts, however four horses $(2,6,12$ and 59) showed thrombocytopenia. The reduced platelet counts in these animals can be explained by the deposition of immune complexes and subsequent degradation by mononuclear phagocytes (Crawford et al. 1996). Another important factor in the infection by EIAV is that the activated macrophages release cytokines such as TNF $\alpha$ (Tumor Necrosis Factor $\alpha$ ), FCT $\beta$ (Growth Factor Transformer $\beta$ ) and interleukin 6, which cause suppression of megakaryocytes colony, progenitor cell platelets (Leroux et al. 2004, Cook et al. 2013).

Only one horse (59) presented severe anemia characterized by a blood test containing levels of red blood cells, hemoglobin and hematocrit, far below the physiological values for the species. The anemia cases occur because EIAV is adsorbed by the erythrocytes, so the circulating complement and the antibodies bind to the virus and remove the circulating erythrocytes more rapidly than normal, resulting in anemia (Issel et al. 2012). This change also occurs due to a reduction in erythropoiesis because of the constant release of TNF $\alpha$ (Cook et al. 2013). The results of WBC in average values for the negative and positive horses are shown in Table 1. No significant differences were observed among positive and negative animals for levels of total leukocytes, lymphocytes, neutrophils, eosinophils and monocytes.

Horse 37 showed relative lymphocytosis, change that according to Thomassian (2005) can be found in horses 
Table 1. Average and standard deviations found for red cells (Rc), hemoglobin (Hb), hematocrit (Ht), VGM, CHGM, platelets, leukocites, lymphocytes, neutrophils eosinophils and monocytes, in negative e positive animals for equine infectious anemia

\begin{tabular}{lcccc}
\hline & Negative & Positive & p-values & Reference* \\
\hline Rc (x106/uL3) & $7,040 \pm 1,00$ & $6,040 \pm 1,30$ & 0,0076 & $6,8-12,9$ \\
$\mathrm{Hb}(\mathrm{g} / \mathrm{dL})$ & $10,73 \pm 1,35$ & $11,33 \pm 6,43$ & 0,65 & $11-19$ \\
$\mathrm{Ht}(\%)$ & $34,51 \pm 4,10$ & $30,84 \pm 7,94$ & 3,79 & $32-53$ \\
VGM (fL) & $49,48 \pm 4,18$ & $54,55 \pm 5,49$ & 0,0018 & $37-58,5$ \\
CHGM (\%) & $31,02 \pm 0,77$ & $30,37 \pm 0,73$ & 0,0106 & $31-37$ \\
Platelets (103/uL) & $230,52 \pm 76,76$ & $182,37 \pm 103,31$ & 0,0950 & $100-350$ \\
Leukocytes mm3 & $12,99 \pm 2,52$ & $11,71 \pm 3,06$ & 0,517 & $5,4-14,3$ \\
Lymphosytes/mm3 & $5862,28 \pm 1457,16$ & $5934 \pm 1646,65$ & 0,151 & $1500-7700$ \\
Neutrophils/mm3 & $6130,20 \pm 2119,90$ & $5084,62 \pm 2980,72$ & 0,197 & $2260-8580$ \\
Eosinphils/mm3 & $586,52 \pm 285,52$ & $558,17 \pm 299,09$ & 0,0778 & $0-1000$ \\
Monocytes/mm3 & $304 \pm 141,41$ & $247,19 \pm 79,23$ & 0,1516 & $0-1000$ \\
* Kaneko et al. (1997). & & & &
\end{tabular}

Table 2. Average and standard deviations found for urea and creatinine, aspartate aminotransferase (AST), alanine aminotransferase (ALT), gamma glutamyl transferase (GGT), alkaline phosphatase (PAL), total bilirubin (TB), direct bilirubin (DB), in negative e positive animals for equine infectious anemia

\begin{tabular}{lcccc}
\hline & Negative & Positive & p-values & Reference $^{\mathrm{a}}$ \\
\hline Urea (mg/dL) & $46 \pm 7,44$ & $42,85 \pm 9,16$ & 0,5417 & $21-51$ \\
Creatinine (mg/dL) & $1,36 \pm 0,52$ & $1,39 \pm 0,23$ & 0,6961 & $1,2-1,9$ \\
AST & $193,69 \pm 69,12$ & $188,22 \pm 41,28$ & 0,7564 & $0-366$ \\
ALT & $10,35 \pm 5,58$ & $11,22 \pm 5,0$ & 0,5731 & 0,23 \\
GGT & $58,82 \pm 37,65$ & $72,21 \pm 55,38$ & 0,2801 & $0-62$ \\
PAL & $394,96 \pm 206$ & $420,92 \pm 232,53$ & 0,6695 & $0-395$ \\
TB & $0,63 \pm 0,30$ & $0,61 \pm 0,35$ & 0,7877 & $1,0-2,0$ \\
DB & $0,45 \pm 0,23$ & $0,54 \pm 0,28$ & 0,2093 & $0-0,04$
\end{tabular}

* Kaneko et al. (1997).

with equine infectious anemia. This signal is characteristic of animals affected by viral infection. Horse 4 showed leukocytosis with neutrophils, common change in animals with bacterial infection, what can be explained by the fact that horses positive for EIA have a weakened immune systems and are susceptible to other diseases (Leroux et al. 2004). The plasma serum protein levels for positive animals averaged $9.59 \pm 0.88 \mathrm{~g} / \mathrm{dL}$ and $9.5 \pm 0.73 \mathrm{~g} / \mathrm{dL}$ for negative animals, and there were no statistically significant differences or changes when compared with normal values for the species, what may range from 8 to $10 \mathrm{~g} / \mathrm{dL}$ (Thrall et al. 2006).

In the evaluation of renal function, the biochemical analyzes revealed averages of $41.46 \pm 7.44$ for urea and $42.85 \pm 9,16 \mathrm{mg} / \mathrm{dL}$ for creatinine, and $1.36 \pm 0.52$ and $1.39 \pm 0.23 \mathrm{mg} / \mathrm{dL}$ for negative and positive animals respectively (Table 2). No significant differences were observed in the results between the positive and negative animals. However, three horses that were seropositive (6, 7 and 35) presented higher blood urea nitrogen than the ones considered normal for the species. According to Doherty \& Valverde (2008) high urea levels indicate kidney damage and horses with infectious anemia develop glomerulitis as result of the accumulation of immune complexes in the basal membranes of the glomeruli (Riet-Correa et al. 2007, Franco \& Paes 2011, Cook et al. 2013).
The average levels found, for negative and positive horses, AST, ALT, GGT, alkaline phosphatase, total bilirubin and direct bilirubin are shown in Table 2. Although there was no significant difference in the evaluated data, the averages of positive animals for the anemia virus were superior. This probably occurred as a result of the inflammation caused by immune-mediated destruction of platelets in the liver as explained by Clabough et al. (1991).

Regarding the liver function, we observed both positive and negative animals presented changes in AST, ALT, GGT, and Alkaline phosphatase. AST and ALT enzymes are present in the cytoplasm of hepatocytes, while GGT is present in the membrane of these cells, as the alkaline phosphatase is in the cell membrane of biliary canaliculi ells. Thus, any disease that causes inflammation or swelling of the liver parenchyma causes increase of these enzymes (Thrall et al. 2006). Due to the harsh conditions in which the horses on Marajó Island live, these changes in the negative animals may be related to other diseases which also occur with liver damage.

For seropositive horses on Marajó Island, the data of hematological and biochemical tests were not relevant to improve the diagnosis for EIA, since seronegative animals also showed changes, which could be explained by the fact that most of the horses in this study were in an hidden stage of the disease, when hematological and biochemical clinical symptoms are less obvious than those found in acute or early infection phases (Montelaro et al. 1993).

\section{CONCLUSIONS}

The equine infectious anemia (EIA) is endemic in the municipalities of Cachoeira do Arari, Salvaterra, Santa Cruz do Arari and Soure, located on Marajó Island, and that high serum positivity rate is favored by both the ecological conditions of the region that favor the population of bloodsucking insect vectors, and by the lack of prophylaxis and control measures for EIA, making it very difficult to stop proliferation of the disease.

Given the importance of EIA for the horse population on Marajó Island, it is essential to draw up an official health program for the Amazon region, in order to control the disease and ensure continued prosperity of local breeds and the improvement of horse breeding in the region. 
Acknowledgements.- The authors would like to thank Conselho Nacional de Desenvolvimento Científico e Tecnológico (CNPq) process number 457233 / 2014-1, Fundação Amazônia Paraense de Amparo a Pesquisa (FAPESPA), INCT Informação Genético-Sanitária da Pecuária.

Conflict of interest statement.- the authors have no competing interests.

\section{REFERENCES}

Almeida V.M.A., Gonçalves V.S.P., Martins M.F., Haddad J.P.A., Dias R.A., Leite R.C. \& Reis J.K.P. 2006. Anemia infecciosa equina: prevalência em equídeos de serviço em Minas Gerais. Arq. Bras. Med. Vet. Zootec. 58:141-148.

Brasil 2004. Instrução Normativa № 45, de 15 de junho de 2004. Aprova as normas para a prevenção e o controle da anemia infecciosa equina (AIE). Diário Oficial da República Federativa do Brasil, Secretaria de Defesa Agropecuária, Brasília.

Brasil 2007. Governo Federal. Grupo Executivo Interministerial. Plano de Desenvolvimento Territorial Sustentável para o Arquipélago do Marajó: resumo executivo da versão preliminar para discussão nas consultas, Brasília.

Campos K.F., Oliveira C.H.S., Reis A.B., Yamasaki E.M., Brito M.F., Andrade S.J.T., Duarte M.D. \& Barbosa J.D. 2013. Surto de encefalomielite equina Leste na Ilha de Marajó, Pará. Pesq. Vet. Bras. 33:443-444.

Clabough D.L., Gebhard D., Flaherty M.T., Whetter L.E., Perry S.T., Coggins L. \& Fuller F.J. 1991. Immune-mediated thrombocytopenia in horses infected with equine infectious anemia virus. J. Virol. 65:6242-6251.

Coggins L., Norcross N.L. \& Nusbaum S.R. 1972. Diagnosis of equine infectious anaemia by immunodifusion test. Am. J. Vet. Res. 33:11-18.

Cook R.F., Leroux C. \& Issel J. 2013. Equine infectious anemia and equine infectious anemia virus in 2013: A review. Vet. Microbiol. 167:181-204

Crawford T.B., Wardrop K.J., Tornquist S.J., Reilich E., Meyers K.M. \& McGuire T.C.A. 1996. Primary production deficit in the thrombocytopenia of equine infectious anemia. J. Virol. 70:7842-7850.

Doherty T. \& Valverde A. 2008. Manual de Anestesia e Algesia em Equinos. Roca, São Paulo. 334p.

Franco M.M.J. \& Paes A.C. 2011. Anemia infecciosa equina: revisão de literatura. Vet. Zootec. 18:197-207.

Gregg K. \& Polejaeva I. 2009. Risk of equine infectious anemia virus disease transmission through in vitro embryo production using somatic cell nuclear transfer. Theriogenology 72:289-299.
Heinemann M.B., Cortez A., Souza M.C.C., Gotti T., Homem V.S.F., Ferreira J.S., Soares R.M., Sakamoto S.M., Cunha E.M.S. \& Richtzenhain L.J. 2002. Soroprevalência da anemia infecciosa equina, da arterite viral dos eqüinos e do aborto viral equino no município de Uruará, PA, Brasil. Braz. J. Vet. Res. Anim. Sci. 39:50-53.

Issel C.J. \& Foil L.D. 1984. Studies on equine infectious anemia virus transmission by insects. J. Am. Vet. Med. Assoc. 184:293-297.

Issel C.J., Scicluna M.T., Cook S.J., Cook R.F., Caprioli A., Ricci I., Rosone F., Craigo J.K., Montelaro R.C. \& Autorino G.L. 2012. Challenges and proposed solutions for more accurate serological diagnosis of equine infectious anaemia. Vet. Rec. 172:1-8.

Kaneko J.J., Harvey J.W. \& Bruss M.L. 1997. Clinical Biochemistry of Domestic Animals. Academic Press, San Diego. 932p.

Karam C.H.V., Rolim M.F., Graça F.A.Z. \& Aragão A.P. 2010. Anemia infecciosa eqüina no estado do Rio de Janeiro: aspectos epidemiológicos, clínicos e laboratoriais. Revta Eletrôn. Novo Enfoque 9:1-13.

Leroux C., Cadoré J.L. \& Montelaro R.C. 2004. Equine Infectious Anemia Virus (EIAV): what has HIV's country cousin got to tell us? Vet. Res. 35:485-512.

Marques J.R.F., Costa M.R. \& Silva A.O.A. 2001. Banco de Recursos Genéticos Animais. Biotecnologia Ciênc. Desenvolv. 21:32-39.

Melo R.M., Cavalcanti R.C., Villalobos E.M.C., Cunha E.M.S., Lara M.C.C.S.H. \& Aguiar D.M. 2012. Ocorrência de equídeos soropositivos para os vírus das encefalomielites e anemia infecciosa no estado de Mato Grosso. Arqs Inst. Biológico, São Paulo, 79:169-175.

Montelaro R.C., Ball J.M. \& Rushlow K.E. 1993. Equine retroviruses, p.257359. In: Levy (Ed.), The Retroviridae. Plenum Press, New York.

Pena I.J., Pena D.A., Barrios P.R., Dale R., Lamêgo M.R.A. \& Moraes M.P. 2006. Levantamento soro-epidemiológico da infecção pelo vírus da Anemia Infecciosa Equina, da Influenza Equina-2 e do Herpesvírus Equino-1 em rebanhos do sul do Estado do Pará, Brasil. Braz. J. Vet. Res. Anim. Sci. 43:537-542.

Riet-Correa F., Schild A.L., Lemos R.A.A. \& Borges J.R. 2007. Doenças de Ruminantes e Equídeos. $3^{a}$ ed. Palloti, Santa Maria. 722p.

Thomassian A. 2005. Enfermidades dos Cavalos. 4aㅡ ed. Varela, São Paulo. 385p.

Thrall M.A., Weiser G., Allison R.W. \& Campbell T.W. 2006. Hematologia e bioquímica clínica veterinária. Roca, São Paulo. 688p. 